The Arts of Cinema 



\title{
The Arts of Cinema
}

\author{
Martin SeEL
}

Translated by Kizer S. Walker

Cornell University Press

ITHACA AND LONDON 
Copyright ( 2018 by Cornell University

Originally published as: "Die Künste des Kinos"

c) S. Fischer Verlag GmbH, Frankfurt am Main 2013.

All rights reserved. Except for brief quotations in a review, this book, or parts thereof, must not be reproduced in any form without permission in writing from the publisher. For information, address Cornell University Press, Sage House, 512 East State Street, Ithaca, New York 14850. Visit our website at cornellpress.cornell.edu.

The translation of this work was funded by Geisteswissenschaften International-Translation Funding for Humanities and Social Sciences from Germany, a joint initiative of the Fritz Thyssen Foundation, the German Federal Foreign Office, the collecting society VG WORT and the German Publishers \& Booksellers Association.

First published 2018 by Cornell University Press

Printed in the United States of America

Library of Congress Cataloging-in-Publication Data

Names: Seel, Martin, author. I Walker, Kizer Sessoms, translator. I Translation of: Seel, Martin. Kunste des Kinos.

Title: The arts of cinema / Martin Seel ; translated by Kizer S. Walker.

Other titles: Kunste des Kinos. English Description: Ithaca : Cornell University Press, 2018. I Includes bibliographical references and index.

Identifiers: LCCN 2018001957 (print) I LCCN 2018002560 (ebook) | ISBN 9781501724855 (epub/mobi) | ISBN 9781501724862 (pdf) | ISBN 9781501709913 | ISBN 9781501709913 (cloth : alk. paper) | ISBN 9781501726170 (pbk. : alk. paper)

Subjects: LCSH: Motion pictures-Aesthetics. I Motion picturesPhilosophy. I Motion pictures and the arts.

Classification: LCC PN1995 (ebook) | LCC PN1995 .S4113 2018 (print) | DDC 791.4301-dc23

LC record available at https://lccn.loc.gov/2018001957 